\title{
Performance and Nutrient Status of Crop Contents of Indigenous, Vanaraja and Crossbred Chickens under Scavenging System
}

\author{
I.U. Sheikh¹, N. Kalita², J.D. Mahanta' ${ }^{1}$, R. Islam³ ${ }^{3}$ K. Barman ${ }^{4}$
}

10.18805/ajdfr.DR-1717

\begin{abstract}
Background: Indigenous birds are low producer of egg and meat due to poor genetic potential. So, improved dual type backyard chicken rearing can increase egg and meat production in the rural areas. Scavenge feed resource is also an important factor on the performance of rural chicken. The nutrient status of these birds under scavenging system shall help to take future steps in this area Methods: A study was conducted on 600 numbers (200 each of Indigenous, Vanaraja and Crossbred) chicken. The day old chicks were distributed in a contiguous area for convenience of the study. Accordingly 30 farmers (10 numbers of farmers for each group) were selected randomly and 20 numbers of chicks were provided to each of them for rearing. The chicks were brooded for initial three weeks by the beneficiaries by their traditional methods and different parameters were recorded.

Result: The final body weights and part period egg production up to 52 weeks of age were found to differ significantly $(P \leq 0.05)$ among the types of chicken. The egg size was significantly $(P \leq 0.05)$ different. Significantly $(P \leq 0.05)$ higher percentage of Crude protein $(C P)$ and Crude fibre (CF) and lower Nitrogen free extract (NFE) of the crop contents were recorded in Vanaraja than Indigenous and Crossbred chickens. The mean CP contents of crop were significantly $(P \leq 0.05)$ highest in Vanaraja $(10.24 \pm 0.37 \%)$ and lowest $(9.16 \pm 0.29 \%)$ in Crossbred chicken. The mean CF contents of crop were differed significantly $(P \leq 0.05)$ among the type of birds. The mean NFE content was significantly $(P \leq 0.05)$ different among the types of chicken. The study showed that the nutrient concentrations of scavengeable feed resources consumed by rural poultry were below the recommended levels for optimum growth and egg production.
\end{abstract}

Key words: Body weight, Composition, Crop contents, Egg production, Scavenge chicken.

\section{INTRODUCTION}

Indian poultry sector witnessed a major success story in the present era in the field of agricultural production system. During the last four decades the scientific poultry production in India started with a rapid rate due to strenuous efforts taken by the private sectors in a comprehensive mode which helped the industry to reach present stage besides certain policies of the Government of India and the focused research of various institutions / organizations. Poultry are generally maintained by rural women and children as a subsidiary business to generate cash revenue but besides supplying adequate eggs and meat to household diet (Das et al., 2008). Livestock and poultry keeping can protect the rural farmers against drought and other natural calamities unlike crops. In India mainstream of the people $(72.22 \%)$ living in rural areas and the majority of the rural livestock householders' engaged in poultry rearing (89\%) as an important source of additional cash earnings (Khandait et al., 2011). There is a great variation in the consumption pattern of egg and meat. The consumption is more by many folds in urban or semi urban area while the rural and tribal areas have little access due to less production as well as low purchasing power; therefore poultry production has to be increased in rural areas to meet their needs. The requirement of eggs and meat of rural areas to be met by backyard poultry rearing has been suggested by many workers (Gayatri et al., 1998; Nandi et al., 2007; Panda et al., 2008). From the welfare point of view, stress free and harmful residues free birds can be grown through backyard poultry production practices
'Department of Poultry Science, College of Veterinary Science, Assam Agricultural University, Khanapara, Guwahati-7810 22, Assam, India.

2Directorate of Research (Vety.), College of Veterinary Science, Assam Agricultural University, Khanapara, Guwahati-781 022, Assam, India.

${ }^{3}$ Biswanath College of Agriculture, Assam Agricultural University, Biswanath Chariali-784 176, Assam, India.

${ }^{4}$ ICAR-National Research Centre on Pig, Rani, Guwahati-781 131, Assam, India.

Corresponding Author: I.U. Sheikh, Division of Livestock Production and Management, Sher-e-Kashmir University of Agricultural Sciences and Technology-Kashmir, Jammu and Kashmir, India. Email: sheikhiu@gmail.com

How to cite this article: Sheikh, I.U., Kalita, N., Mahanta, J.D., Islam, R. and Barman K. (2021). Performance and Nutrient Status of Crop Contents of Indigenous, Vanaraja and Crossbred Chickens under Scavenging System. Asian Journal of Dairy and Food Research. DOI: 10.18805/ajdfr.DR-1717.

Submitted: 12-05-2021 Accepted: 23-08-2021 Online: 18-09-2021

(Khandekar, 2003; Mandal et al., 2006). Rural backyard chickens scavenge around the homestead areas and eat kitchen waste, leftover cereal grains like rice, wheat, pulses, green grasses, insects, other available feedstuffs etc. and convert them to produce a good quality, cheap source of animal protein (Das et al., 2008). Traditional backyard poultry production contributed greatly to the nutritional security, 
household income and employment generation which play a major role in upliftment of the rural economy and women empowerment. Though the rural backyard poultry is still contributing significantly to the national egg production (30\%) but still remain the most neglected one (Tajane and Vasulkar, 2014).

Native chickens are hardy, disease resistance, camouflage and better meat quality compared to commercial broilers. Owing to the better taste and flavor of meat and eggs and higher disease resistance in native chicken besides fetching higher prices, there is a rising trend in customer and farmer preference to native chickens (Umaya, 2014). The lower egg production of the Indigenous, Vanaraja and Crossbred birds under scavenging system of rearing is mostly due to less availability of scavenging feed resources. Therefore, the present study was conducted to evaluate the nutrient status of these birds under scavenging system so that necessary step can be taken to improve their performances.

\section{MATERIALS AND METHODS}

A total of 600 numbers chicks (200 each of Indigenous, Vanaraja and Crossbred-PB2 $x$ Indigenous) were procured for rearing under backyard systems. A pilot study was conducted to find out a locality in where there was a potentiality for poultry production and farmers were also interested for the same. The day old chicks were distributed in a contiguous area for convenience of the study. From Bijaynagar area of Kamrup district, Assam, India 30 farmers (10 numbers of farmers for each group) were selected randomly and each of them 20 number of chicks were provided. The chicks were brooded for initial three weeks by the beneficiaries by their traditional methods. They made small enclosure inside the house with help of straw and paddy husk were put as bedding material and incandescent bulb of 200 watt was used for heating purposes. After three weeks the birds were let loose in the early morning to scavenge in their backyard and nearby field. Vaccination and medications were provided as and when needed. The body weight of all the birds were recorded at $10^{\text {th }}$ week, at first egg and 50 weeks of age in the early morning before the birds let loose for scavenging. The age at first egg and part period egg production was recorded up to 52 weeks of age.

For proximate study 30 birds i.e. 10 birds ( 5 male and 5 female) birds from each of Indigenous, Vanaraja and Crossbred chicken were selected randomly for collection of crop contents. The birds were directly collected from different households in the evening hours between 4.00 P.M. to 5.00 P.M., when the birds were at the end of the day's scavenging. They were slaughtered on the spot and each bird was eviscerated, the crop was opened and the contents were collected and weighed. The crop contents were then dried under sunlight and weighed. The dried crop contents were ground after the grits and other inanimate objects had been removed and were analysed for proximate components
AOAC (2005). The calcium and phosphorus were estimated (Talapatra et al., 1940). The True metabolizable energy (TME) of the crop contents was calculated by using the formula of Wiseman (1987). Metabolizable energy (ME) was then determined on the basis of TME by assuming that TME was 8 per cent higher than the ME, since TME is noted to be 5-10 per cent higher than the ME (Wiseman,1987). The data were analysed as per the methods of Snedecor and Cochran (1994).

\section{RESULTS AND DISCUSSION Body weights}

The body weights at $10^{\text {th }}$ week, age at first egg and 50 weeks were found to differ significantly $(\mathrm{P} \leq 0.05)$ among the types of chicken (Table 1). The body weights were found to be higher in Vanaraja followed by Crossbred and Indigenous chickens under scavenging rearing system. Similar findings were also reported by Krishna et al. (2007) who recorded higher body weight gain in coloured layers compared to desi birds. Significantly $(P \leq 0.05)$ higher body weight in Vanaraja compared to Indigenous chicken was recorded by few workers (Ramana et al., 2010 and Gonmei et al., 2016). Pathak et al. (2015) reported significantly $(P<0.05)$ higher body weight in Crossbred than Indigenous birds. Sankhyan and Thakur (2016) also recorded significantly $(P \leq 0.05)$ higher body weight in Vanaraja birds compared to Indigenous chicken at $20^{\text {th }}$ and $40^{\text {th }}$ weeks of age. The body weight of Indigenous chicken was recorded lower than Vanaraja and Crossbred, as the lighter and compact body of Indigenous chickens help them to escape from predators in free range system of rearing. Also lower response to improved feeding contributed to lower body. The higher body weight in Vanaraja is attributed to the fact that this chicken variety has been developed by crossing random bred meat control population as the female line and Red Cornish population as the male line and Crossbred may be attributed to the broiler inheritance of PB2, which is a synthetic broiler line.

\section{Age at first egg}

The age at first egg was $186.30 \pm 0.26,166.50 \pm 0.0 .23$ and $178.10 \pm 0.34$ days for Indigenous, Vanaraja and Crossbred chicken under scavenging system. Sankhyan et al. (2013) also reported similar age at first egg in Vanaraja chicken (168 days) under scavenging system. However, early age at first egg (140-156 days) in Vanaraja chicken recorded by Singh et al. (2018) and late age at first egg (187.45 to 190 days) in Vanaraja was reported by (Islam et al., 2014; Banja et al., 2017; Sarma et al., 2018). Ramana et al. (2010) found significantly lower $(P \leq 0.05)$ age at sexual maturity in Vanaraja than Indigenous chicken. Jha et al. (2012) recorded significantly $(P \leq 0.05)$ lower age at sexual maturity in Vanaraja than desi chicken.

\section{Egg production}


The part period egg production up to 52 weeks of age of Indigenous, Vanaraja and Crossbred chicken were recorded as $29.60 \pm 0.18,60.00 \pm 0.23$ and $52.50 \pm 0.29$ numbers respectively under scavenging rearing system which differ significantly $(\mathrm{P} \leq 0.05)$ among the types of chicken (Table 1) The egg production was highest in Vanaraja and lowest in indigenous birds under scavenging system. Significant $(\mathrm{P} \leq 0.05)$ differences in egg production among the types of chicken could be due to differences in genetic make up for higher egg production. Also Vanaraja has been developed for egg and meat production for rural areas by incorporating superior germplasm and PB2 is a synthetic male line broiler which contributed more egg production in Crossbred chicken than the Indigenous chicken. The higher egg production in Vanaraja and Crossbred chicken might be due to lack of broody character unlike the Indigenous chicken. Also early attainment of age at first egg in Vanaraja and Crossbred chicken contributes to the higher egg production.

The results of present study was in agreement with Krishna et al. (2007) who reported a significantly $(\mathrm{P} \leq 0.05)$ higher egg production in the coloured birds than desi birds. Sola-Ojo and Ayorinde (2011) recorded that the total number of eggs laid by the Crossbred was higher than those of purebred. Pathak et al. (2015) reported significantly $(\mathrm{P}<0.05)$ higher egg production in Crossbred than Indigenous birds. Sankhyan and Thakur (2016) recorded significantly $(P \leq 0.05)$ higher egg production in Vanaraja than that of Indigenous chicken upto 52 weeks of age. Sharma et al. (2018) also reported significantly $(\mathrm{P} \leq 0.05)$ higher egg production in Vanaraja than Indigenous chicken.

\section{Egg size}

The egg size recorded at $52^{\text {nd }}$ weeks of age was $37.50 \pm 0.35$, $56.28 \pm 0.38$ and $49.32 \pm 0.33 \mathrm{~g}$ for Indigenous, Vanaraja and Crossbred chicken under scavenging system. The results in egg weight are in accordance with other workers (Ramana et al., 2010; Kalita et al., 2011; Jha et al., 2012; Islam et al., 2014; Sahu et al., 2016; Sharma et al., 2018; Choudhary et al., 2019) who were recorded significantly $(P \leq 0.05)$ higher egg weights in Vanaraja than that of the Indigenous chicken. Pathak et al. (2015) reported significantly $(P<0.05)$ higher egg weight in Crossbred than Indigenous birds. Sankhyan and Thakur (2016) also recorded significantly $(P \leq 0.05)$ higher egg weight in Vanaraja than those of Indigenous chicken.

\section{Proximate composition of crop contents}

The proximate composition of crop contents of different types of chicken under backyard systems of rearing at 52 weeks of age is presented in Table 2. The mean dry matter (DM) contents were recorded as $47.45 \pm 0.74,47.82 \pm 0.53$ and $47.63 \pm 0.62$ per cent, respectively for Indigenous, Vanaraja and Crossbred chicken, which differed non-significantly among them.

The mean organic matter $(\mathrm{OM})$ contents were recorded as $87.64 \pm 0.38,87.96 \pm 0.30$ and $87.33 \pm 0.34$ per cent, respectively for Indigenous, Vanaraja and Crossbred chicken, which differed non-significantly among them.

The mean crude protein (CP) contents were recorded as $9.63 \pm 0.24,10.24 \pm 0.37$ and $9.16 \pm 0.29$ per cent, respectively for Indigenous, Vanaraja and Crossbred chicken, which differed significantly $(P \leq 0.05)$ among themselves.

The mean crude fibre (CF) contents were recorded as $6.55 \pm 0.31,8.08 \pm 0.26$ and $6.67 \pm 0.53$ per cent, respectively for Indigenous, Vanaraja and Crossbred chicken, which differed significantly $(P \leq 0.05)$ among the different types of chickens.

The mean ether extract $(E E)$ contents were recorded as $2.19 \pm 0.07,2.02 \pm 0.11$ and $2.07 \pm 0.06$ per cent, respectively for Indigenous, Vanaraja and Crossbred chicken, which differed non-significantly among the different types of chickens.

The mean total ash contents were recorded as $12.36 \pm 0.38,12.04 \pm 0.04$ and $12.67 \pm 0.34$ per cent, respectively for Indigenous, Vanaraja and Crossbred chicken, which differed non-significantly among them.

The mean nitrogen free extract (NFE) contents for Indigenous, Vanaraja and Crossbred chicken were recorded as $69.27 \pm 0.60,67.62 \pm 0.54$ and $69.23 \pm 0.40$ per cent, respectively.

The NFE contents was found to be significantly $(P \leq 0.05)$ higher in Indigenous and Crossbred chicken in compared to Vanaraja chicken.

The mean Calcium and Phosphorus content for Indigenous, Vanaraja and Crossbred chicken were estimated $1.07 \pm 0.22$ and $0.28 \pm 0.14,1.02 \pm 0.26$ and $0.30 \pm 0.12$ and $0.98 \pm 0.28$ and $0.27 \pm 0.11$ per cent respectively.

In the present study all the types of chicken reared under backyard system were allowed to scavenge all around the

Table 1: Bodyweight, age at first egg, egg size and egg production of different types of birds under scavenging system.

\begin{tabular}{lcccccr}
\hline Types of chicken & \multicolumn{3}{c}{ Body weight $(\mathrm{g})$} & & Age at first egg & \multicolumn{2}{c}{$\begin{array}{c}\text { Egg production } \\
\text { Egg size }\end{array}$} \\
\cline { 2 - 4 } & 10 weeks & At first egg & 50 weeks & (days) & Upto 52 weeks & $(\mathrm{g})$ \\
\hline Indigenous & $370.22^{\mathrm{a}} \pm 3.13$ & $1120.25^{\mathrm{a}} \pm 7.38$ & $1289.96^{\mathrm{a}} \pm 15.56$ & $186.30 \pm 0.26$ & $29.60^{\mathrm{a}} \pm 0.18$ & $37.50^{\mathrm{a}} \pm 0.35$ \\
Vanaraja & $898.34^{\mathrm{b}} \pm 7.18$ & $2068.81^{\mathrm{b}} \pm 16.39$ & $2568.45^{\mathrm{b}} \pm 35.64$ & $166.50 \pm 0.0 .23$ & $60.00^{\mathrm{b}} \pm 0.23$ & $56.28^{\mathrm{b}} \pm 0.38$ \\
Crossbred & $502.27^{\mathrm{c}} \pm 6.11$ & $1412.53^{\mathrm{c}} \pm 9.46$ & $2041.32^{\mathrm{c}} \pm 18.73$ & $178.10 \pm 0.34$ & $52.50^{\mathrm{c}} \pm 0.29$ & $49.32^{\mathrm{c}} \pm 0.33$ \\
\hline
\end{tabular}

Means with different superscripts in a column differed significantly $(\mathrm{P} \leq 0.05)$. 
households in farmers premises during day time and little hand feeding was done in the form of kitchen waste, broken rice and paddy.

The results of the present study were comparable with Rashid et al. (2004) who reported that the mean DM contents of crop as $45.5 \pm 7.40$ and $48.9 \pm 7.06$ per cent for local scavenging layer and grower in Bangladesh and the mean $\mathrm{CP}, \mathrm{EE}, \mathrm{CF}$, ash, NFE, calcium and total phosphorus of the crop contents were $11.7 \pm 2.53,2.07 \pm 0.95,6.04 \pm 2.98$, $12.4 \pm 5.51,68.3 \pm 7.80,1.32 \pm 0.79$ and $0.46 \pm 0.18$ per cent respectively for layers on DM basis. Rashid et al. (2005) reported that the average DM content of crop was 47.80 \pm 7.50 per cent. The mean CP, EE, CF, crude ash, NFE, calcium and phosphorus were $10.50 \pm 2.2,2.10 \pm 1.50$, $6.40 \pm 3.50,12.50 \pm 7.80,68.70 \pm 8.60,0.96 \pm 0.67$ and $0.38 \pm 0.18$ per cent on DM basis, respectively for Indigenous scavenging chicken in Bangladesh. Rahman and Howlider (2006) reported that the mean CP, CF, ash, calcium, phosphorus $11.72,8.46,13.36,0.40$ and 0.33 per cent, respectively on DM basis in scavenging chickens in Bangladesh. Goromela et al. (2008) reported the average DM and CP of crop contents was 50.30 and 9.24 per cent in village poultry of central Tanzania.

In contrary to the present findings, Pousga et al. (2005) recorded higher values in DM, ash and EE per cent and lower values of OM, CF per cent in crop contents of local and Crossbred pullet chicken under scavenging condition in two agro-ecological regions in Burkina Faso. Mekonnen et al. (2010) recorded the higher mean DM, CP and EE per cent in crop contents of scavenging chickens in Ethiopia. The higher values of EE and ash per cent in crop and gizzard contents than the present study was recorded in scavenging chickens of both sexes in Central Tanzania (Goromela et al., 2007). The present study showed that the nutrient concentrations of scavengeable feed resources consumed by rural poultry were below the recommended levels for optimum growth and egg production.

Momoh et al. (2010) recorded higher values of DM, CP, EE, CF and ash per cent and lower value of NFE per cent in crop contents of layer and grower chicken under scavenging system. Mutayoba et al. (2011) reported the higher values $\mathrm{CP}, \mathrm{CF}, \mathrm{EE}$ and ash per cent and lower values of NFE per cent on DM basis for chick, grower and adult chickens respectively.

The CP of crop contents of the present study was lower than the ICAR (2013) recommended level of CP (18\% for layers). The variation in the nutrient composition of crop contents might be due to variation in scavenged feed base resources, harvesting season or dry season, nibbling abilities of the bird and the nutrient requirement of the bird for maintenance, growth and production.

The mean Calcium and Phosphorus content for Indigenous, Vanaraja and Crossbred chicken were estimated $1.07 \pm 0.22$ and $0.28 \pm 0.14,1.02 \pm 0.26$ and $0.30 \pm 0.12$ and $0.98 \pm 0.28$ and $0.27 \pm 0.11$ per cent

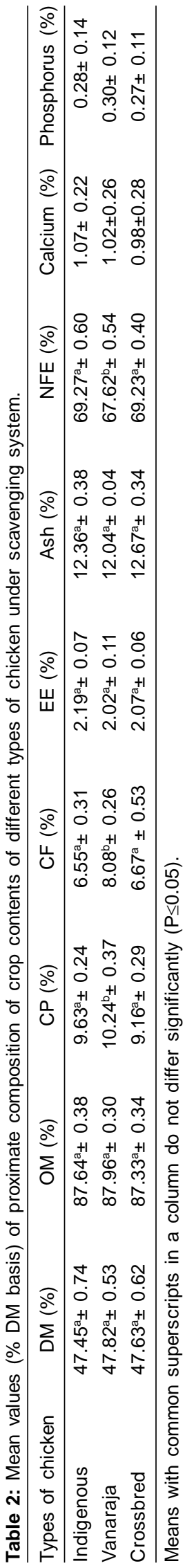

Asian Journal of Dairy and Food Research 
Table 3: Average dried weights $(\mathrm{g})$ of crop contents and $\mathrm{ME}(\mathrm{Kcal} / \mathrm{kg})$ contents of different types of chicken under scavenging system.

\begin{tabular}{lccccc}
\hline Types of chicken & $\begin{array}{c}\text { Average dried } \\
\text { weight of crop }(\mathrm{g})\end{array}$ & $\begin{array}{c}\text { ME content } \\
(\text { Kcal/kg) }\end{array}$ & $\begin{array}{c}\text { ME (Kcal) } \\
\text { intake/ bird/day }\end{array}$ & $\begin{array}{c}\text { CP content } \\
(\%)\end{array}$ & $\begin{array}{c}\text { CP }(\mathrm{g}) \\
\text { intake/bird/day }\end{array}$ \\
\hline Indigenous & 20.38 & 2746.07 & 167.70 & $9.63 \pm 0.24$ & 5.89 \\
Vanaraja & 30.45 & 2624.72 & 239.77 & $10.24 \pm 0.37$ & 9.35 \\
Crossbred (PB2x Indigenous) & 25.24 & 2718.64 & 205.86 & $9.16 \pm 0.29$ & 6.94 \\
\hline
\end{tabular}

respectively which were far below the recommended level (NRC,1994). The value of calcium is lower and phosphorus is similar than that reported by Momoh et al. (2010). Rahman and Howlider (2006) also reported lower values of calcium and similar phosphorus level as recorded in the present study.

\section{Weight of crop contents}

The average dried weight of crop contents of different types of chickens were recorded as 20.38, 30.45 and $25.24 \mathrm{~g}$ for Indigenous, Vanaraja and Crossbred chickens respectively. The dried weight $(\mathrm{g})$ of the crop contents were within the range reported by Rashid et al. (2004) and Rashid et al. (2005) in local scavenging layer chickens in Bangladesh, Mekonnen et al. (2010) in scavenging chickens in Ethiopia and Pousga et al. (2005) in local and crossbred pullet chicken under scavenging condition in Burkina Faso.

\section{Metabolizable energy of crop contents}

The metabolizable energy (ME) of the crop contents were calculated as 2746.07, 2624.72 and $2718.64 \mathrm{Kcal} / \mathrm{kg}$ respectively for Indigenous, Vanaraja and Crossbred chickens (Table 3) under scavenging rearing system. Similar ME values were reported by Rashid et al. (2004) as $2781 \pm 336 \mathrm{Kcal} / \mathrm{kg}$ and Rashid et al. (2005) as $2747 \pm 419$ $\mathrm{Kcal} / \mathrm{kg}$ in local scavenging layer chickens in Bangladesh. However, higher values of ME were reported by Mekonnen et al. (2010) in crop content of scavenging chickens in Ethiopia (3404.30 - 3636.20 Kcal/kg). The differences might be due to variation in season (harvesting or non-harvesting), scavengeable feed resource base (SFRB) and nibbling habits of the birds, requirement for maintenance, growth and egg production. The ME of crop contents in the present study was lower than the NRC (1994) recommended level (2900 Kcal/kg).

\section{Metabolizable energy and crude protein intake}

The metabolizable energy (ME) intake per bird per day was 167.70, 239.77 and 205.86 Kcal respectively for Indigenous, Vanaraja and Crossbred chickens under scavenging rearing system. The Crude protein intake was recorded as 5.89 , 9.35and $6.94 \mathrm{~g}$ per day per bird respectively for Indigenous, Vanaraja and Crossbred chickens under scavenging rearing system (Table 3 ). The scavenge chicken started nibbling continuously from morning onwards and pauses feeding, when the crops and gizzard are completely filled and takes rest for sometimes. Nibbling begins once again when digestion starts i.e. the ingested feed starts moving from these organs and occurs frequently during a day (Ajuyah, 1999). Based on these points, it is believed that birds fill their crops fully approximately three times in a day. Therefore, on the basis of the results of the present study, the Indigenous, Vanaraja and Crossbred chicken might manage to pickup 5.89, 9.35 and $6.94 \mathrm{~g} \mathrm{CP}$ and 167.70, 239.77 and $205.86 \mathrm{Kcal} \mathrm{ME}$ per day per bird respectively from the scavenging feed resources available in the study area which is far below the recommended level (NRC, 1994). Similar values were also recorded by Rashid et al. (2005) in local scavenging layer chickens in Bangladesh.

\section{CONCLUSION}

From the present study, it could be concluded that the concentration of nutrients (except Crude Fibre) available to the Indigenous, Vanaraja and Crossbred chicken under scavenging condition of the present study area was far below the requirements for optimum growth and production. Therefore, the birds should be provided supplementary feeding in the form grains, kitchen waste etc. in the morning and evening hours especially during dry season to express the performance as per genetic potential of these chickens under scavenging system.

\section{ACKNOWLEDGEMENT}

The authors are highly thankful to Director of Research (Veterinary), Assam agricultural University Khanapara, Guwahati for providing necessary facilities to carry out the study in time and the beneficiaries of the study for their cooperation during the data collection.

\section{Conflict of interest}

The authors declare that they have no conflict of interest.

\section{REFERENCES}

A.O.A.C. (2005). Official methods of analysis of the Association of Official Analytical Chemists International. USA: Maryland.

Ajuyah, A.O. (1999). Novel pairing technique for estimating feed intake and nutrient digestability by scavenging village chickens. Free communication 7, The first INFPD/FAO Electric conference on Family Poultry. FAO, Rome, Italy. nhttp://www.fao.org/ag/aga/AGAP/LPA/fampol/fampo.htm available onlineat http://www.academicjournals.org/AJAR

Banja, B.K., Ananth, P.N., Singh, S., Sahoo, P.R. and Jayasankar, P. (2017). Assessment of a new backyard poultry strain "Kaveri" in farmer's situation, rural Odisha, India. Journal of World's Poultry Research. 7(1): 08-14. 
Choudhary, R.K., Roy, M.K. and Sohane, R.K. (2019). Livelihood upliftment of tribal farmers through backyard poultry farming intervention in Kishanganj district of Bihar. Journal of Agri Search. 6: 90-92.

Das, S.C., Chowdhury, S.D. Khatun, M.A. Nishibori, M. Isobe, N. and Yoshimura, Y. (2008). Poultry production profile and expected future projection in Bangladesh. World's Poultry Science Journal. 64: 99-117.

Gayatri, H.R., Kemparaja and Narayanswamy, B.K. (1998). Role of women in small scale poultry production in rural India. Scientific proceeding of Second Pan Commonwealth Veterinary Conference, Vol. 1, Banglore.

Gonmei, G., Barua, N., Kalita, N. and Borpuzari, R.N. (2016). Productive Performance of Indigenous and Vanaraja chicken under Deep litter system of rearing. International Journal of Veterinary Sciences and Animal Husbandry. 1(1): 06-07.

Goromela, E.H., Kwakkel, R.P., Verstegen, M.W.A. and Katule, A.M. (2008). Effect of season and farming system on the quantity and nutritional quality of scavengeable feed resources and performance of village poultry in central Tanzania. Journal of Cell and Animal Biology. 2(3): 63-71.

Goromela, E.H., Kwakkel, R.P., Verstegen, M.W.A. and Katule, A.M. (2007). Identification, characterisation and composition of scavengeable feed resources for rural poultry production in Central Tanzania. African Journal of Agricultural Research. 2(8): 380-393.

ICAR (2013). Nutrient Requirements for Poultry. Indian Council of Agricultural Research New Delhi. India.

Islam, R., Kalita, N. and Nath, P. (2014). Comparative performance of Vanaraja and Indigenous chicken under backyard system of rearing. Journal of Poultry Science and Technology. 2(1): 22-25.

Jha, D.K., Prasad, S., Soren, S.K. and Mahto, D. (2012). Performance of Vanaraja birds under deep litter system of management. Indian Veterinary Journal. 89(1): 75-76.

Kalita, N., Barua, N., Chutia, H., Islam, R., Pathak, N. and Kalita, R. (2011). Egg quality and carcass characteristics of Vanaraja and indigenous chicken reared under intensive system. Indian Veterinary Journal. 88(10): 66-68.

Khandait, V.N, Gawande, S.H., Lohakare, A.C. and Dhenge, S.A. (2011). Adoption Level and Constraints in Backyard Poultry Rearing Practices at Bhandara District of Maharashtra (India), Research Journal of Agricultural Sciences. 2(1): 110-113.

Khandekar, N. (2003). Future Development of Backyard poultry in India. Poultry Year Book. pp: 73-76.

Krishna, C.H., Mahender, M., Ramana, D.B.V. and Chandra, A.S. (2007). Performance of coloured layers under backyard rearing system in South Telangana region of Andhra Pradesh. Indian Journal of Animal Production and Management. 23(1-4): 102-106.

Mandal, M.K., Khandekar, N. and Khandekar, P. (2006). Backyard poultry farming in Bareilly district of Uttar Pradesh, India: An analysis. Livestock Research for Rural Development, Vol.18, Article \#101. http://www.Irrd.org//rrd18/7/mand 18101.htm.
Mekonnen, H., Mulatu, D., Kelay, B. and Berhan, T. (2010). Assessment of the nutritional status of indigenous scavenging chickens in Ada'a district, Ethiopia. Tropical Animal Health and Production 42:123-130.

Momoh, O.M., Egahi, J.O., Ogwuche, P.O. and Etim, V.E. (2010). Variation in nutrient composition of crop contents of scavenging local chickens in North Central Nigeria. Agriculture and Biology Journal of North America. 1(5): 912-915.

Mutayoba, S.K, Katule, A.K., Minga, U., Mtambo, M.M. and Olsen, J.E. (2011). Seasonal variation in nutritive value of scavenged feed and effect of supplementation on performance of rural birds. Agriculture and Biology Journal of North America. 2(9): 1310-1316.

Nandi, S., Sharma, K., Kumar, P. and Nandi, D. (2007). Poultry farming: A rapidly growing profitable business. Poultry Line. 7(12): 19-20.

Panda, A.K, Raju, M.V.L.N. and Rama Rao, S.V. (2008). Poultry production in India: Opportunities and challenges ahead. Poultry Line. 8(1): 11-14.

Pathak, S.S., Kalita, N. and Barua, N. (2015). Comparison of egg quality characteristics of indigenous and broiler parent line crossed with indigenous chicken. The Indian Journal of Veterinary Sciences and Biotechnology. 11(3):12-16.

Pathak, S.S., Kalita, N. and Barua, N. (2015). Productive and reproductive performances of indigenous and broiler parent line crossed with indigenous chickens. The Indian Journal of Veterinary Sciences and Biotechnology. 11(1): 56-60.

Pousga, S., Boly, H., Lindberg, J.E. and Ogle, B. (2005). Scavenging pullets in Burkina Faso: Effects of season, location and breed on feed and nutrient intake. Tropical Animal Health and Production. 37(8): 623-634.

Rahman, M.S. and Howlider, M.A.R. (2006). Nutrients availability to scavenging chickens in Bangladesh. International Journal of Poultry Science. 5(3): 275-278.

Ramana, D.V.B., Nirmala, G., Maruthi, V. and Rap, G.R. (2010). Performance of Vanaraja birds as backyard poultry. Indian Veterinary Journal. 87(5): 517- 518.

Rashid, M., Roy, B.C. and Asaduzzaman (2004). Chemical Composition of Crop Contents of Local Scavenging Chickens. Pakistan Journal of Nutrition. 3(1): 26-28.

Rashid, M.M., Islam, M.N., Roy, B.C., Jakobsen, K. and Lauridsen, C. (2005). Nutrient concentration of crop and gizzard contents of indigenous scavenging chicken under rural conditions of Bangladesh. Livestock Research for Rural Development. Vol. 17: Art. \#16. http://www.Irrd.org//rrd17/ 2/rash17016.htm.

Sahu, B., Kumar, F., Singh, M., Mukherjee, K., Patel, B. and Jain, V. (2016). Production performance and egg weight of Vanaraja layer bird in Chhattisgarh. International Journal of Science, Environment and Technology. 5(6): 43284333.

Sankhyan, V. and Thakur, Y.P. (2016). Comparative performance of Vanaraja and Indigenous chicken under intensive system in sub temperate climatic condition of north western Himalayan state of Himachal Pradesh. International Journal of Science, Environment and Technology. 5(2): 449-453. 
Sankhyan, V., Katoch, S., Thakur, Y.P., Dinesh, K., Patial, S. and Bhardwaj, N. (2013). Analysis of characteristics and improvement strategies of rural poultry farming in north western Himalayan state of Himachal Pradesh, India. Livestock Research for Rural Development. Volume 25, Article \#211. Retrieved March 25, 2020, from http:// www.Irrd.org//rrd25/12/sank25211.htm.

Sarma, M., Islam, R., Borah, M.K., Sharma, P., Mahanta, J.D., Kalita, N. and Bhattacharyya, B.N. (2018). Comparative performance of Vanaraja, Srinidhi and Desi chicken under traditional system among tribal community of Assam. Indian Journal of Animal Research. 52(10): 1518-1520.

Singh, M., Talimoa, Mollier, R.T., Rajesha G., Nguillie, A.M., Rajkhowa, D.J., Rajkumar, U., Paswan, C. and Chatterjee, R.N. (2018). Backyard poultry farming with Vanaraja and Srinidhi: proven technology for doubling the tribal farmers' income in Nagaland. Indian Farming. 68(01): 80-82.

Snedecor, G.W. and Cochran, W.G. (1994). Statistical Methods. $8^{\text {th }}$ Edn, Affiliated East West Press Pvt. Ltd., New Delhi.
Sola-Ojo, F.E. and Ayorinde, K.L. (2011). Evaluation of reproductive performance and egg quality traits in progenies of dominant Black Strain Crossed with Fulani Ecotype Chicken. Journal of Agricultural Science. 1(3): 258-265.

Tajane, S.B. and Vasulkar, R. (2014). Development of rural backyard poultry. Poultry Punch 30(3): 30 and 35.

Talapatra, S.K., Ray, S.C.and Sen, K.C. (1940). Estimation of phosphorus, chlorine, calcium, magnesium, sodium and potassium in foodstuffs. Indian Journal of Veterinary Sciences and Animimal Husbandry. 10: 243-246.

Umaya, S.R. (2014). The uniqueness of immunocompetence and meat quality of native chickens: a specialized review, World Journal of Pharmacy and Pharmaceutical Sciences. 3(2): 2576-2588.

Wiseman, J. (1987). Feeding of Non-ruminant Livestock. Butterworths, London, UK, pp. 9-13. 